\title{
Brexit and Tourism
}




\section{ASPECTS OF TOURISM}

Series Editors: Chris Cooper, Leeds Beckett University, UK,

C. Michael Hall, University of Canterbury, New Zealand and Dallen J. Timothy, Arizona State University, USA.

Aspects of Tourism is an innovative, multifaceted series, which comprises authoritative reference handbooks on global tourism regions, research volumes, texts and monographs. It is designed to provide readers with the latest thinking on tourism worldwide and in so doing will push back the frontiers of tourism knowledge. The series also introduces a new generation of international tourism authors writing on leading edge topics.

The volumes are authoritative, readable and user-friendly, providing accessible sources for further research. Books in the series are commissioned to probe the relationship between tourism and cognate subject areas such as strategy, development, retailing, sport and environmental studies. The publisher and series editors welcome proposals from writers with projects on the above topics.

All books in this series are externally peer-reviewed.

Full details of all the books in this series and of all our other publications can be found on http://www.channelviewpublications.com, or by writing to Channel View Publications, St Nicholas House, 31-34 High Street, Bristol BS1 2AW, UK. 


\title{
Brexit and Tourism
}

Process, Impacts and Non-Policy

\author{
Derek Hall
}


DOI https://doi.org/10.21832/HALL7123

Library of Congress Cataloging in Publication Data

A catalog record for this book is available from the Library of Congress.

Names: Hall, Derek R., author.

Title: Brexit and Tourism: Process, Impacts and Non-Policy/Derek Hall.

Description: Bristol, UK; Blue Ridge Summit, PA: Channel View

Publications, 2020. | Series: Aspects of tourism; 86 | Includes

bibliographical references and index. | Summary: 'This book offers a

multidisciplinary, holistic appraisal of the implications of the UK's

withdrawal from the European Union (EU) for tourism and related

mobilities. It attempts to look beyond the short- to medium-term

consequences of these processes for both the UK and the EU' - Provided

by publisher.

Identifiers: LCCN 2019029541 (print) | LCCN 2019029542 (ebook) | ISBN

9781845417116 (paperback) | ISBN 9781845417123 (hardback) | ISBN

9781845417130 (pdf) | ISBN 9781845417147 (epub) | ISBN 9781845417154

(kindle edition) Subjects: LCSH: Tourism - Great Britain. | Tourism - European

Union countries. | European Union - Great Britain.

Classification: LCC G155.G7 H35 2020 (print) | LCC G155.G7 (ebook) | DDC $338.4 / 7914-\mathrm{dc} 23$

LC record available at https://lccn.loc.gov/2019029541

LC ebook record available at https://lccn.loc.gov/2019029542

British Library Cataloguing in Publication Data

A catalogue entry for this book is available from the British Library.

ISBN-13: 978-1-84541-712-3 (hbk)

ISBN-13: 978-1-84541-711-6 (pbk)

Channel View Publications

UK: St Nicholas House, 31-34 High Street, Bristol, BS1 2AW, UK.

USA: NBN, Blue Ridge Summit, PA, USA.

Website: www.channelviewpublications.com

Twitter: Channel_View

Facebook: https://www.facebook.com/channelviewpublications

Blog: www.channelviewpublications.wordpress.com

Copyright (C 2020 Derek Hall and contributors.

All rights reserved. No part of this work may be reproduced in any form or by any means without permission in writing from the publisher.

The policy of Multilingual Matters/Channel View Publications is to use papers that are natural, renewable and recyclable products, made from wood grown in sustainable forests. In the manufacturing process of our books, and to further support our policy, preference is given to printers that have FSC and PEFC Chain of Custody certification. The FSC and/or PEFC logos will appear on those books where full certification has been granted to the printer concerned.

Typeset by Riverside Publishing Solutions.

Printed and bound in the UK by Short Run Press Ltd.

Printed and bound in the US by NBN. 